\title{
ANALISIS FAKTOR-FAKTOR PENYEBAB PEMBIAYAAN BERMASALAH PADA BMT AT TAQWA CABANG BANDAR BUAT PADANG
}

\author{
Annisa Rosalinda, Jhon Fernos \\ Akademi Keuangan dan Perbankan "Pembangunan" \\ annisarosalinda932@gmail.com
}

\begin{abstract}
The research objective was to find out how to analyze the causes of problems at BMT At Taqwa Cabang Bandar Buat Padang. The data analysis method is descriptive using quantitative and qualitative analysis methods. Where the qualitative method is a method used to obtain related information through interviews with BMT At Taqwa Cabang Bandar Buat Padang and using quantitative methods, namely the method used to perform calculations by processing data in table form. The result of the research on the development rate of the number of Non-Performing Financing in 2018 was 16,55\% and decreased in 2019 by 9,84\% and in 2020 it increased by 17,02\%. Problem financing at BMT At Taqwa cabang Bandar Buat Padang is caused by internal and external factors, internal factors, namely factors that come from within, such as not beig accurate in analyzing financing and monitoring / supervision that has not been maximed by BMT. Meanwhile, external factors are factors caused by outside parties, such as a decrease in customer operating income and the customer deliberately delays financing.
\end{abstract}

Keywords: Troubled Financing, BMT At Taqwa

\section{PENDAHULUAN}

Menurut UU No. 10 Tahun 1998 Bank adalah suatu badan usaha yang berjalan di bidang keuangan yang menerima simpanan dari masyarakat dan memberikan pinjaman kepada masyarakat (pembiayaan atau kredit) dan atau / bentuk lainnya yang bertujuan untuk meningkatkan taraf perekonomian masyarakat. Menurut Ensiklopedia Islam, Bank Islam adalah badan usaha yang menyalurkan pembiayaan dan jasa-jasa dalam lalu lintas pembayarannya berdasarkan syariat Islam dalam pengoperasiannya (Sumar'in 2012).

Secara sederhana, bank diartikan sebagai lembaga usaha yang kegiatannya adalah menerima dana dari masyarakat dan memberikannya lagi kepada masyarakat yang membutuhkan serta jasa bank lainnya (Kasmir 2014). Lembaga keuangan terdiri dari lembaga keuangan bank dan lembaga keuangan non bank, lembaga keuangan non bank merupakan badan keuangan yang kegiatannya hanya menyalurkan dana yang mempunyai ciri-ciri usahanya sendiri (Yusuf 2015).

Lembaga keuangan selama ini sudah banyak dikenal masyarakat adalah lembaga keuangan bank. Lembaga keuangan tersebut ada yang syariah dan konvensional. Selain lembaga keuangan yang berbentuk perbankan, ada juga lembaga keuangan yang memiliki visi dan misi keutamaan yang jelas dan beroperasi berdasarkan syariah islam, cuman produk manajemennya sedikit 
berbeda dengan lembaga keuangan perbankan, seperti Baitul Maal Wa Tamwil (BMT), Asuransi Syariah dan Reksadana Syariah, lembaga yang berhubungan langsung dengan masyarakat kecil adalah BMT (Yusuf 2015).

Baitul Maal Wa Tamwil (BMT) adalah badan usaha yang menitikberatkan bayt al-mal wa al-tamwil dengan aktivitas mengembangkan usaha-usaha yang menguntungkan dan investasi yang dapat meningkatkan kualitas perekonomian terutama bagi pengusaha kecil kebawah dan mendorong kegiatan menabung serta dapat menunjang kegiatan pembiayaan (Khotimah 2016).

Sebagai lembaga keuangan syariah, BMT memiliki tugas pokok yang memperoleh dana dari masyarakat dalam bentuk simpanan dan sekaligus memberikan bantuan kepada masyarakat yang kekurangan dana dalam bentuk pembiayaan untuk melanjutkan usaha berdasarkan prinsip syariah islam (Supriadi Muslimin 2017). Pembiayaan yang disalurkan oleh BMT merupakan kegiatan utama BMT yang bertujuan untuk meningkatkan perekonomian masyarakat, akan tetapi kegiatan pembiayaan tersebut tidak berjalan dengan lancar atau baik, karena adanya pihak yang melakukan penyalahgunaan dana sehingga terjadi pembiayaan bermasalah atau macet. Ukuran keberhasilan penyaluran pembiayaan adalah kolektibilitas, yaitu tingkat pengembalian atau pembayaran dengan menentukan kualitas suatu pembiayaan, kualitas pembiayaan juga ditentukan oleh kinerja usaha dari nasabah pembiayaan yang bersangkutan sehingga dapat memperoleh untung atau laba, namun dalam pembiayaan tersebut BMT dihadapkan dengan persoalan pembiayaan bermasalah atau disebut juga dengan Non Performing Financing (NPF) (Jatun 2015).

Menurut peraturan Menteri Negara Koperasi dan Usaha Kecil Menengah (UMKM) RI No. 35.3/Per/M.KUKM/2007 tentang pedoman penilaian kesehatan koperasi jasa keuangan syariah dan unit jasa keuangan syariah dengan ketetapan bahwa rasio pembiayaan bermasalah KJKS dan UJKS agar dikatakan sehat sebesar $5 \%$ dari total pembiayaan yang disalurkan.

Sebagaimana lembaga keuangan pada umumnya baitul maal wat-tamwil (BMT) At Taqwa Muhammadiyah Cabang Bandar Buat melakukan kegiatan penghimpunan dana dan penyaluran dana kepada masyarakat pengusaha kecil. Produk penyaluran pembiayaan yang tersedia pada BMT At Taqwa Muhammadiyah Padang Cabang Bandar Buat adalah pembiayaan dalam bentuk Murabahah, Ba'i Bitsaman Ajil dan Qardhul Hasan.

Tabel 1

Total Pembiayaan, Pembiayaan Bermasalah pada

BMT At Taqwa Cabang Bandar Buat Padang

Periode 2018-2020

(dalam Rp. 000)

\begin{tabular}{ccrr}
\hline No & Tahun & Total Pembiayaan & Total Pembiayaan Bermasalah \\
\hline 1 & 2018 & 2.169 .847 & 359.115 \\
2 & 2019 & 2.563 .121 & 252.467 \\
3 & 2020 & 2.878 .604 & 489.963 \\
\hline
\end{tabular}

Sumber Tabel 1.1 : BMT At Taqwa Cabang Bandar Buat, data olahan 
Pada tabel 1 diatas terlihat jumlah pembiayaan pada tahun 2018 adalah sebesar Rp. 2.169.847.000 kemudian mengalami peningkatan pada tahun 2019 sebesar Rp. 2.563.121.000 dan pada tahun 2020 terjadi peningkatan sebesar Rp. 2.878.604.000. Jumlah pembiayaan bermasalah pada tahun 2018 adalah sebesar Rp. 359.115.000 dan mengalami penurunan pada tahun 2019 sebesar Rp. 252.467.000 dan pada tahun 2020 mengalami peningkatan lagi sebesar Rp. 489.963.000. Pada tahun 2020 ini terjadi pembiayaan bermasalah paling tinggi dikarenakan ekonomi masyarakat yang tidak stabil akibat wabah covid-19 sehingga nasabah tidak mampu untuk membayar angsurannya.

\section{METODE PENELITIAN}

\section{Metode Pengumpulan Data}

Untuk keperluan penelitian ini, pengumpulan data dilakukan dengan dua cara yaitu: a.studi lapangan (Field Research) yaitu penulis langsung turn kelapangan untuk melengkapi data yang diperlukan. Penelitian dilapangan dapat melakukan dengan mewawancarai bagan pihak yang berkepentingan sesuai dengan instansi yang terkait. b, studi perpustakaan( Library Research) yaitu penelitian ini dilakukan kepustaka dengan mencari informasi melalui buku-buku ilmiah dan tulisan-tulisan yang berhubungan dengan pembahasan yang dilakukan.

\section{Metode Analisis Data}

Adapun metode analisis data yang digunakan adalah metode kualitatif dan kuantitatif. Dimana metode kualitatif merupakan metode yang dilakukan untuk mendapatkan informasi terkait melalui wawancara terhadap BMT At Taqwa Cabang Bandar Buat Padang dan menggunakan metode kuantitatif, dimana kegiatannya adalah data yang bersumber dari laporan keuangan berupa angkaangka. Dalam metode ini, penulis menjelaskan data secara fakta yang dialami sesuai dengan teori yang ada

\section{HASIL DAN PEMBAHASAN \\ Pengertian BMT ( Baitul Maal Wattamwil )}

Baitul Maal Wattamwil merupakan suatu lembaga yang terdiri dari dua istilah, yaitu Baitul Maal dan Baitul Tamwil, Baitul Maal biasanya mengarah pada penghimpunan dan penyaluran dana yang non profit. Adapun baitul maal sebagai usaha penghimpunan dan pemberian dana komersial (Supriadi Muslimin 2017), Baitul maal wattamwil (BMT) adalah badan usaha usaha yang isi nya bayt al-mal wa-tamwil dengan mengembangkan usaha-usaha yang menguntungkan dan pendanaan dalam mengembangkan perekonomian pengusaha kecil kebawah untuk membantu kegiatan menabung dan pembiayaan (Khotimah 2016).

\section{Pengertian Pembiayaan}

Pembiayaan berarti pembelanjaan, yaitu dana yang berguna untuk mendukung kegiatan pendanaan yang telah dipersiapkan oleh diri sendiri maupun orang lain. Dalam arti sempit, pembiayaan adalah pendanaan yang telah dilakukan oleh lembaga pembiayaan, seperti bank syariah kepada nasabah (Hutami and Triyanto 2016). Pembiayaan adalah aktivitas atau kegiatan bank yang 
menggunakan prinsip syariah dalam penyaluran dana kepada pihak lain selain bank (Hidayah, Nawawi, and Arif 2018).

\section{Fungsi Pembiayaan}

Pembiayaan memiliki fungsi yang sangat diperlukan dalam perekonomian, perdagangan, keuangan yang dikemukakan sebagai berikut: a. Menjadi motivasi dan dinamika dalam meningkatkan ekonomi masyarakat. b. Pembiayaan dapat meningkatkan efisiensi (daya guna) dari modal / uang. c. Pembiayaan untuk mengembangkan sirkulasi dan lalu lintas uang. d. Pembiayaan merupakan alat yang berguna untuk idle fund, sehingga bank dapat menemukan pihak yang memiliki kelebihan dana dan pihak yang kekurangan dana, untuk mengatasi gap antara pihak yang membutuhkan dana.. (Firaldi 2012). e. Pembiayaan digunakan sebagai alat untuk menstabilkan ekonomi dan memperbaiki ekonomi yang kurang sehat. f. Pembiayaan untuk pengendalian harga. g. Pembiayaan dapat meningkatkan peredaran barang.

\section{Pengertian Pembiayaan Bermasalah}

Pembiayaan bermasalah adalah pembiayaan yang telah disalurkan oleh bank kepada nasabah, dan nasabah tidak mampu membayar angsuran sesuai dengan yang perjanjian yang ditandatangani oleh pihak yang bersangkutan bank. Pembiayaan bermasalah mengakibatkan kerugian pada bank, yaitu tidak diterimanya kembali dana yang telah disalurkan maupun pendapatan margin, artinya bank tidak mendapatkan keuntungan, yang dapat menurunkan pendapatan secara total (Turmudi 2016).

\section{Analisis Faktor-Faktor Penyebab Pembiayaan Bermasalah Pada BMT At Taqwa Cabang Bandar Buat Padang Syarat-Syarat Pemberian Pembiayaan Kepada Calon Debitur}

Syarat-syarat pemberian pembiayaan kepada calon debitur oleh BMT At Taqwa Cabang Bandar Buat Padang: a. Pihak yang berakad : 1) Sebagai keabsahan suatu perjanjian (akad) para pihak harus cakap hukum 2) Sukarela (ridho), tidak dalam keadaan terpaksa / dipaksa dan tidak dalam tekanan. b. Objek yang diperjualbelikan 1) Barang yang diperjualbelikan tidak boleh barang yang dilarang (haram), dan memberikan manfaat serta tidak cacat. 2) Merupakan hak milik penuh pihak yang berakad. 3) Sesuai kesepakatan antara yang diserahkan penjual dan yang diterima pembeli. c. Sighat / Akad 1) Harus jelas dan disebutkan kepada (siapa) dan pihak yang berakad 2) Ijab Kabul (serah terima) harus searah dan jelas baik dalam detail barang (penjelasan fisik barang) maupun harga yang telah disepakati oleh pemberi dan penerima pembiayaan.3) Tidak bersifat menggantungkan dasar transaksi pada kejadian yang akan datang. 4) Tidak terbatas waktu.

\section{Prosedur Pemberian Pembiayaan Kepada Calon Debitur}

Prosedur pemberian pembiayaan merupakan upaya BMT At Taqwa Cabang Bandar Buat Padang dalam mengurangi risiko dalam pemberian pembiayaan dan langkah-langkah sebagai berikut: a. Sebelum pembiayaan dicairkan, berdasarkan wawancara penulis dengan Account Officer BMT At Taqwa Cabang Bandar Buat, beliau menjelaskan prosedur pemberian pembiayaan 
dilakukan dengan tahapan sebagai berikut: 1) Pengajuan permohonan pembiayaan, tahapan ini, calon nasabah mengajukan surat permohonan pembiayaan dengan mengisi surat permohonan pembiayaan, dengan melampirkan fotocopy KK, fotocopy buku nikah, fotocopy jaminan seperti STNK, BPKB, sertifikat tanah, dll. 2) Periksa Kelengkapan Administrasi, tahapan ini pihak BMT (AO) akan meneliti surat permohonan pembiayaan serta lampiran persyaratan untuk melihat kebenaran data nasabah. 3) Survey langsung kelapangan / lokasi, Account Officer kemudian melakukan survey kelapangan untuk melihat usaha nasabah, lokasi usaha nasabah, jaminan nasabah, serta tempat tinggal nasabah. 4) Account Officer membuat analisis pembiayaan, setelah survey maka tahapan selanjutnya adalah dengan menganalisa usaha nasabah, analisa karakter nasabah dengan menggunakan prinsip 5C atau yang berkaitan dengan kondisi secara keseluruhan calon nasabah, dan setelah di analisa diajukan kepada manager. 5) Keputusan Pembiayaan, setelah hasil analisis diajukan pada manager untuk ditinjau kembali apakah jumlah pembiayaan yang diajukan nasabah layak diberikan atau tidak. Apabila pembiayaan diterima atau disetujui maka pembiayaan dapat dicairkan, nasabah harus menandatangani berkas sebelum pencairan dilakukan antara lain berkas tersebut terdiri dari surat persetujuan fasilitas pembiayaan, akad pembiayaan, surat kuasa, surat pernyataan asuransi jaminan, setelah semua berkas ditandatangani maka dilakukan verifikasi data terakhir, baru dicairkan. b. Setelah Pembiayaan Dicairkan, prosedur yang dilakukan oleh BMT At Taqwa Cabang Bandar Buat setelah pembiayaan dicairkan. Berdasarkan hasil wawancara dengan Account Officer menyebutkan bahwa langkah-langkah yang dilakukan setelah pembiayaan dicairkan adalah dengan melakukan pengawasan pembiayaan / monitoring yang berkaitan dengan usaha nasabah.

Tabel. 2

Tingkat Perkembangan Jumlah Pembiayaan dan Pembiayaan Bermasalah Pada BMT At Taqwa Cabang Bandar Buat Padang Periode 2018-2020

(Dalam Rp.000)

\begin{tabular}{ccccrc}
\hline No & Tahun & $\begin{array}{c}\text { Jumlah } \\
\text { Pembiayaan } \\
(\mathbf{1})\end{array}$ & \multicolumn{4}{c}{$\begin{array}{c}\text { Jumlah Pembiayaan } \\
\text { Bermasalah } \\
\text { (2) }\end{array}$} & (2) : (1) \\
\hline 1 & 2018 & 2.169 .847 & 0 & 359.115 & $16,55 \%$ \\
2 & 2019 & 2.563 .121 & $18,12 \%$ & 252.467 & $9,84 \%$ \\
3 & 2020 & 2.878 .604 & $12.30 \%$ & 489.963 & $17,02 \%$ \\
\hline
\end{tabular}

Sumber : BMT At Taqwa Cabang Bandar Buat Padang, data olahan

Berdasarkan tabel 2 terlihat tingkat perkembangan jumlah pembiayaan bermasalah pada tahun 2018 sebesar $16,55 \%$ dan mengalami penurunan pada tahun 2019 sebesar 9,84\% dan pada tahun 2020 mengalami kenaikan sebesar $17,02 \%$. Jika pembiayaan bermasalah terus meningkat tiap tahunnya maka BMT akan mengalami kerugian, hal ini disebabkan karena banyaknya nasabah yang tidak tepat waktu dalam membayarkan kewajibannya dan jumlah jaminan yang tidak sesuai dengan jumlah yang dipinjam. 


\section{Penyebab Pembiayaan Bermasalah}

Pembiayaan bermasalah menjadi salah satu penyakit yang bisa menghambat perkembangan sektor jasa keuangan. Apa yang menjadi penyebab terjadinya hal tersebut. Pembiayaan bermasalah disebabkan oleh beberapa faktor yaitu a. faktor Internal 1) Kurang akurat dalam melakukan analisis pembiayaan dimana Proses analisis yang dilakukan oleh Account Officer (AO) BMT At Taqwa Cabang Bandar Buat Padang yaitu dengan menganalisis karakter nasabah, usaha nasabah, analisis karakter dengan menggunakan prinsip 5C belum dilakukan dengan teliti dan mendalam sehingga hasil analisis menjadi kurang akurat, adanya kelemahan dalam menganalisis karakter nasabah yang menyebabkan kurang akuratnya hasil analisis pembiayaan yang menjadi faktor internal yang mempengaruhi terjadinya pembiayaan bermasalah. Apabila analisis karakter dilakukan secara teliti dalam mengecek kebenaran hasil wawancara dengan nasabah kepada orang sekitar seperti saudara, tetangga, dan orang terdekat di tempat usaha nasabah. Jika dilakukan pula analisis dengan menggunakan prinsip 7P akan membuat hasil analisis jauh lebih akurat dari nasabah tersebut sehingga pembiayaan bermasalah pada BMT dapat diminimalisir. 2) Monitoring / Pengawasan pembiayaan yang dilakukan belum maksimal yaitu pelaksanaan monitoring pembiayaan yang dilakukan BMT At Taqwa Cabang Bandar Buat Padang dilakukan dengan menganalisis pembayaran angsuran dan dengan melakukan pemantauan langsung belum maksimal. Menurut penulis, memonitoring yang dilakukan belum semaksimal mungkin karena hanya dengan melakukan analisis pembayaran angsuran dan melakukan pemantauan langsung ke nasabah ole AO, jika monitoring dilakukan dengan mengidentifikasi masalahmasalah yang akan berdampak pada usaha nasabah, menilai kondisi keuangan, pemantauan terhadap usaha yang nasabah jalankan, pemantauan secara dini terhadap kolektibilitas, dan melakukan pembinaan secara rutin. Menurut analisa penulis, jika hal tersebut dilakukan akan membuat berkurangnya pembiayaan bermasalah. b. Faktor Eksternal dimana terjadi 1) Penurunan pendapatan usaha nasabah yaitu terjadinya penurunan dari usaha nasabah sehingga nasabah tidak dapat membayar kewajiban atau angsuran perbulannya kepada pihak BMT. Menurut analisa penulis, hal tersebut dipengaruhi oleh pendapatan nasabah yang menurun sehingga dalam pengembalian angsurannya tidak sesuai dengan perjanjian dari nasabah.2) Nasabah pembiayaan sengaja dalam melakukan penundaan pembayaran angsuran dimana Adanya itikad kurang baik dari nasabah sengaja melakukan penundaan dalam melakukan pembayaran angsuran yang menyebabkan terjadinya pembiayaan bermasalah (macet). Jika dilakukan analisis karakter nasabah yang mendalam menggunakan prinsip 5C maka akan membuat pembiayaan yang diberikan pada orang yang jujur dalam melakukan pembayaran angsuran sehingga tidak ada nasabah yang sengaja melakukan penundaan dalam membayar angsurannya.

\section{Upaya Penanganan Pembiayaan Bermasalah}

Upaya dalam menangani Pembiayaan Bermasalah dapat dilakukan oleh BMT At Taqwa Cabang Bandar Buat Padang dengan cara a.teguran yaitu dilakukan sebelum jatuh tempo (1 minggu) untuk mengingatkan kepada para anggota bahwa pinjaman akan selesai. a. rescheduling (penjadwalan ulang) 
dengan cara 1). memperingati jangka waktu pembiayaan dengan memberikan peringatan dalam jangka waktu pembayaran dari enam bulan menjadi satu tahun sehingga anggota dapat mengembalikan pembiayaan dalam jangka waktu yang lama. 2). memperpanjang jangka waktu angsuran Dalam hal ini jangka waktu pembiayaan diperpanjang pembayarannya, misalnya dari 56 kali menjadi 70 kali sehingga jumlah angsuran dapat diperkecil sesuai dengan penambahan jumlah angsuran. b. restructuring artinya pihak BMT memberikan tambahan jumlah kredit kepada nasabah tersebut mulai bermasalah dalam angsuran. c. penyitaan jaminan adalah tindakan selanjutnya apabila anggota tidak memiliki Itikad baik dan sudah tidak mampu lagi untuk membayarkan seluruh pembiayaannya. d. eksekusi jaminan adalah BMT melakukan penjualan terhadap barang-barang yang dijadikan jaminan dalam rangka pelunasan hutang. Didalam BMT, penjualan jaminan yang harganya lebih dari hutang anggota, maka kelebihannya akan dikembalikan, tetapi jika hasil penjualan barang jaminan tidak menutupi hutang anggota, maka pihak BMT akan menagih kembali kekurangannya. e. penghapusan Hutang dengan cara 1) hapus Item terjadi karena usaha mengalami penurunan bahkan kebangkrutan tetapi masih mampu untuk mencicil. 2) hapus system dan tagih terjadi karena usaha yang bangkrut serta jatuh miskin dan tidak ada lagi peluang dalam melunasi hutangnya dan akhirnya mereka lari dari tanggung jawab.

\section{PEMBAHASAN}

Tingkat perkembangan jumlah pembiayaan bermasalah pada tahun 2018 sebesar $16,55 \%$ dan mengalami penurunan pada tahun 2019 sebesar 9,84\% dan pada tahun 2020 mengalami kenaikan sebesar 17,02\%. Jika pertumbuhan pembiayaan bermasalah terus meningkat tiap tahunnya maka BMT akan mengalami kerugian, hal ini disebabkan karena banyaknya nasabah yang tidak membayar angsurannya dan pendapatan usaha nasabah yang menurun.

Pembiayaan bermasalah disebabkan oleh berbagai faktor, baik faktor internal maupun eksternal, faktor internal yaitu faktor yang berasal dari dalam bank, seperti pengelolaan pembiayaan yang tidak tegas dan lemah oleh BMT dalam melakukan monitoring atau pengawasan penggunaan pembiayaan, serta kurang akuratnya BMT dalam menganalisis pembiayaan sedangkan faktor eksternal yaitu faktor yang disebabkan dari luar bank, seperti penurunan pendapatan usaha nasabah sehingga menyebabkan kerugian yang menjadi pemicu nasabah tidak mampu membayar angsurannya kemudian juga disebabkan karena nasabah sengaja melakukan penundaan pembayaran angsuran. Kesulitan likuiditas keuangan, kejadian diluar kekuasaan nasabah contohnya bencana alam, perang dan juga watak buruk seorang nasabah.

\section{SIMPULAN}

Berdasarkan uraian tentang faktor pembiayaan bermasalah maka menjadi permasalahan ini adalah Bagaimana Analisis Faktor-Faktor Penyebab Pembiayaan Bermasalah Pada BMT At Taqwa Cabang Bandar Buat Padang. Ada 2 faktorfaktor yaitu faktor internal dan faktor eksternal, faktor internal yaitu faktor yang berasal dari dalam bank, seperti pengelolaan pembiayaan yang tidak tegas dan lemah oleh BMT dalam melakukan monitoring atau pengawasan penggunaan 
pembiayaan, serta kurang akuratnya BMT dalam menganalisis pembiayaan, sedangkan faktor eksternal yaitu faktor yang berasal dari luar bank, seperti penurunan pendapatan usaha nasabah sehingga menyebabkan kerugian yang menjadi pemicu nasabah tidak mampu membayar angsurannya kemudian juga disebabkan karena nasabah sengaja melakukan penundaan pembayaran angsuran. Kesulitan likuiditas keuangan, kejadian diluar kekuasaan nasabah contohnya bencana alam, perang, dan juga watak buruk seorang nasabah.

\section{UCAPAN TERIMA KASIH}

Penulis mengucapkan terima kasih kepada Kepala Cabang dan Kakak di BMT At Taqwa Cabang Bandar Buat Padang yang telah mengizinkan dan membantu penulis dalam memperoleh informasi. Serta semua pihak yang telah membantu penulis dalam penyelesaian artikel ini.

\section{DAFTAR PUSTAKA}

Jatun, Rengganing. 2015. Analisis Faktor - Faktor Yang Berpengaruh Terhadap Keputusan Nasabah Untuk Mengambil Pembiayaan Pada Kospin Jasa Layanan Syariah Pekalongan.

Kasmir, SEMM. 2014. "Bank Dan Lembaga Keuangan Lainnya.” Edisi Revisi 87-97.

Khotimah, Umu. 2016. "Peran Baitul Mal Wat Tamwil (BMT) Al-Ishlah Bobos Dalam Pemberdayaan UMKM (Studi Kasus Pada Masyarakat Desa Bobos Kec. Dukupuntang Kab. Cirebon).” 1-12.

Sumar'in. 2012. "Pengertian, Peranan, Dan Perkembangan Bank Syariah Di Indonesia." 2012 2(1):1-5.

Supriadi Muslimin. 2017. "Peranan Lembaga Keuangan Mikro Syariah Terhadap Pemberdayaan Usaha Mikro Kecil Menengah (Studi Kasus Pada BMT Al Amin Makassar) Skripsi." Journal of Chemical Information and Modeling 53(9):1689-99.

Yusuf, Dr. H.Burhanuddin. 2015. "Buku_MSDM_editor.pdf.” 304.

Firaldi, Mufqi. 2012. “Analisis Pengaruh Jumlah Dana Pihak Ketiga (DPK), Non Performing Financing (NPF) Dan Tingkat Inflasi Terhadap Total Pembiayaan Yang Diberikan Oleh Bank Pembiayaan Rakyat Syariah (BPRS) Di Indonesia." Journal Article 4(12):127.

Hasibuan, Melayu, and Manajemen Dasar. n.d. "Melayu Hasibuan, Manajemen Dasar, Pengertian, Dan Masalah, (Jakarta: Bumi Aksara, 2005), hlm.4. 1 1." 1-20.

Hutami, Hatma Sri Woro, and Andi Triyanto. 2016. "Eksekusi Jaminan Pada Pembiayaan Bermasalah Di BMT Bima Kota Magelang (Telaah Fatwa DSN MUI NO.17/DSN/IX/2000)." Cakrawala: Jurnal Studi Islam 
11(2):204-16. doi: 10.31603/cakrawala.v11i2.252.

Turmudi, Muhammad. 2016. "Manajemen Penyelesaian Pembiayaan Bermasalah Pada Lembaga Perbankan.” Jurnal Studi Ekonomi Dan Bisnis Islam I:5674. 